\title{
Managing Human Capital Development In Small And Medium-Sized Enterprises For Sustainable National Development In Nigeria
}

Christopher O. Chidi, University of Lagos, Nigeria Oluseyi A. Shadare, University of Lagos, Nigeria

\begin{abstract}
This study investigated the challenges confronting human capital development in small and medium-sized enterprises (SMEs) in Nigeria. The authors adopted the survey research design. An instrument was designed using the 5-point Likert scale ranging from strongly agree (5) to strongly disagree (1). The instrument has two sections. Section A has nine items which sought the views and opinions of respondents on the challenges of human capital development in SMEs and Section $B$ has eight items which elicited the demographic profiles of respondents. A total of 165 questionnaires were distributed to the target population using the purposeful (judgmental) sampling technique. Out of the 165 questionnaires administered, 140 were returned upon which the analysis was based. This represents an 85\% response rate. Data analysis was carried out with the aid of SPSS (Statistical Package for Social Sciences). It was found that human capital development in Nigerian SMEs leaves much to be desired. Based on the analysis of data, it was found that $79 \%$ of respondents agreed and strongly agreed that many SMEs have negative training philosophy and pay lip service to human resource development. Seventy percent of the respondents agreed and strongly agreed that many SMEs do not have laid-down policies governing training and development programmes, while 52\% of the respondents agreed and strongly agreed that SMEs engage in human capital development haphazardly, without embarking on need analysis. The authors recommended the need to address the issues of human capital development in SMEs and for SMEs to embrace the investor in people criteria if the desired corporate and national goals are to be realized.
\end{abstract}

Keywords: Human capital development; small and medium-sized enterprises; sustainable national development

\section{INTRODUCTION}

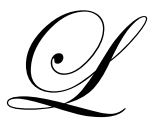

arge organizations have long recognized human capital as part of the mix for superior performance as well as national economic growth (Price, 2004). There is a popular maxim that the human capital or resource is the greatest asset at the disposal of organizations (Okpala \& Chidi, 2010). The workforce of an organization is the stock of human capital it acquires, deploys, and retains in pursuit of profitability, market share, and customer satisfaction (Heneman III \& Judge, 2006). In mission statements, annual reports and annual general meetings, organizations declare that "our greatest assets are our people" (Okpala \& Chidi, 2010). The right quality of human capital makes the difference in organizations the world over and is viewed as an organization's most valuable asset. One of the means of achieving quality staff is through continuous updating of skills through training and retraining of staff at all levels to improve their attitude, skill and knowledge (ASK) and to keep them abreast of latest developments and techniques. This has become imperative in view of the dynamic and competitive business milieu organizations operate and to keep pace with advances in information and communication technology. 
According to Walton (1999), small and medium-sized enterprises (SMEs) have always played a significant part in the national and global economy. The role which SMEs play in developing economies, like Nigeria, is tremendous. This ranges from social, such as stimulation of indigenous entrepreneurship and technology, creation of employment, redistribution of wealth and income, to economic, such as utilization of local resources, dispersal and diversification of economic activities and mobilization of savings (Owuala, 1987, 1999). SMEs in Nigeria and elsewhere are recognized as one of the principal driving forces for sustainable economic development because of their role in job creation, stimulation of entrepreneurial skills, and private ownership of businesses (Katwalo \& Madichie, 2008). According to Fajana (1995), the incidence of the on-going recession possibly meant that in the future, SMEs will continue to increase in number. A study carried out by the Federal Office of Statistics (FOS) indicates that $97 \%$ of all businesses in Nigeria can be grouped as SMEs. This implies that SMEs are the heart and engine of Nigerian economic development (Ariyo, 2000). Studies on Nigerian small and medium-sized enterprises are on the increase in view of the phenomenal proliferation of SMEs in Nigeria. However, many of these studies focused on problems of size and structure (Inegbenebor, 1995), human resources management (Fajana, 1995), management practices organizational effectiveness (Lawal, 2005), problems and prospects of SMEs (Obikoya, 1995), corporate social responsibility and organizational effectiveness (Lawal \& Sulaimon, 2007), to mention a few. In spite of the tremendous role of SMEs as the engine of economic development, there is paucity of research in the area of human capital development in SMEs in the Nigerian environment. This study attempts to add to the existing body of knowledge by focusing on managing the challenges of human capital development in this strategic subsector. For this study, an organization is defined as small if it has 10-49 full-time equivalent employees and medium-sized if it has 50-250 full-time equivalent employees. This size category is consistent with the European Commission (1996) as cited in Walton (1999); Cameron \& Massey (1999), Coetzer (2006), and Pearson, Stringer, Mill \& Summers (2006).

The objective of this study is to examine the challenges of human capital development in small and medium-sized enterprises in Nigeria with a view to fashioning out guidelines for managing human capital development and utilization in this strategic sub-sector for national economic development. Small and medium-sized enterprises, which form the focus of this study, are based in Lagos, which is the commercial nerve centre of Nigeria, with high concentration of small and medium-sized enterprises.

\section{LITERATURE REVIEW}

Attempt is made to review some theoretical and conceptual issues, as well as empirical studies, in the development literature germane to human capital development in small and medium-sized enterprises. Human capital is the bedrock upon which all other organizational resources rest upon. Bontis, Dragonetti, Jacobsen and Roos (1999) defined human capital as representing the human factor in the organization - the combined intelligence, skills and expertise that gives the organization its distinctive character. The human elements of the organization are those that are capable of learning, changing, innovating and providing the creative thrust which, if properly motivated, can ensure the long-term survival of the organization. The theoretical base of this study is the human capital theory. Human capital theory suggests that education or training raises the productivity of workers by imparting useful knowledge and skills, hence, raising workers' future income by increasing their lifetime earnings (Becker, 1964). Based upon the work of Becker (1964), Schultz (1961), Sakamota and Powers (1995), and Psacharopoulos and Woodhall (1997), human capital theory rests on the assumption that formal education and training are highly instrumental and even necessary to improve the production capacity of a population. Human capital theorists argue that an educated population is a productive one. Human capital theory emphasizes how education increases the productivity and efficiency of workers by increasing the level of cognitive stock of economically productive human capability, which is a product of innate abilities and investment in human beings. The provision of formal education is seen as a productive investment in human capital, which the proponents of the theory have considered equally, or even more equally, worthwhile than that of physical capital (Olaniyan \& Okemakinde, 2008). Psacharopoulos and Woodhall (1997) assert that:

Human resources constitute the ultimate basis of the wealth of nations. Capital and natural resources are passive factors of production, human beings are the active agencies who accumulate capital, exploit natural resources, build social, economic and political organization, and carry forward national development (p. 102) 
According to Chung Tzu (as cited in Ojo 1998) "if you wish to plan for a year, sow seeds; if you wish to plan for ten years, plant trees, and if you wish to plan for a lifetime, develop men". Thus, the dearth of human capital is not one of numbers, but a scarcity of trained people with adequate and up-to-date skills and knowledge. Harbison (1973) opined, clearly a country that is unable to develop the skills and knowledge of its people and utilize them effectively in the national economy will be unable to develop anything else. The four key elements of human capital development are training, development, learning, and education.

Armstrong (2006), citing Bass and Vaughan (1966), views learning as "a relatively permanent change in behaviour that occurs as a result of experience or practice". Thus, change in behaviour indicates that learning has taken place. When an individual reacts, behaves or responds as a result of experience in a manner different from the way he/she formerly behaved, then learning has taken place. Learning is the process by which a person acquires and develops new knowledge, skills, capabilities, and attitudes. As Williams (1998) defines it, 'learning is goal-directed; it is based on experience; it impacts behaviour and cognition; and the changes brought about are relatively stable'. Honey and Mumford (1996) explain that 'Learning occurs when people can demonstrate that they know something they did not know before (insights, realizations, as well as facts) and when they can do something they could not do before (skills)'. Mumford and Gold (2004) emphasize that 'Learning is both a process and an outcome concerned with knowledge, skills, and insight.' The concept of training has been variously defined. Obisi (1996), citing Steinmetz (1969), opines that training is viewed as a "short-term process utilizing a systematic and organized procedure by which non-managerial personnel learn technical knowledge and skills for a definite purpose". Fajana (2002) views training as "the process that involves developing skills and learning concepts, rules or attitudes in order to increase effectiveness on a particular job". Armstrong (1984) views training as "the systematic development of the knowledge, skills and attitudes required by an individual to perform adequately a given task or job". The keyword in this definition is "systematic". Systematic training is training that which is specifically designed to meet defined needs; that is, planned training. It is easy to fall into the trap of training for training's sake. Armstrong (2001) states that training is "the formal and systematic modification of behaviour through learning that occurs as a result of education, instruction, development, and planned experience". Training could be viewed as a process of improving a trainee's knowledge, skills, and attitude to make him/her more competent on the job. It is job-specific and job-related. Its overall goal is to bring about performance improvement. Training involves learning and learning is a continuous process.

The concept of development has been variously defined. Obisi (1996), citing Steinmetz (1969), opines that "development is a long-term educational process utilizing a systematic and organized procedure by which managerial personnel learn conceptual and theoretical knowledge for general purpose". Banjoko (2002) views development as "the process of helping managerial employees who perform non-routine jobs to improve their managerial, administrative, and decision-making abilities and competence". Armstrong (2006) posits that management development is "concerned with improving managers' performance in their present roles and preparing them for greater responsibilities in the future". Thus, from the above we can confidently conclude that while training is designed for non-managerial personnel, development is designed for managerial personnel. Education has a longterm maturation process. It is all encompassing and involves the development of the knowledge, values, and understanding required in all aspects of life rather than the knowledge and skills relating to particular areas of activity or job (Armstrong, 2006). Education is a life-long process of knowledge acquisition, which helps an individual to become properly integrated into society. It is a continuous learning process that prepares and assists the individual to blend with the realities of life. It is on the totality of the individual. Countries that are at the forefront of technology also have the most educated population (Van-Den-Berg 2001).

Odekunle (2001) opines that investment in human capital has positive effects on the supply of entrepreneurial activity and technological innovation. Ayeni (2003) asserts that education, as an investment, has future benefits of creation of status, job security, and other benefits in cash and in kind. Since the emergence of human capital theory, the notion of investing in human beings as a form of capital has fueled growing interest in workplace learning theory and practice (Coetzer, 2006, and Boud \& Garrick, 1999).Thus, learning at and through work is imperative for employees to ensure their employability. Knowledge is regarded as a key asset of employees. Learning is important, not only for organizational survival, but also because the ability to learn faster than competitors may be the only competitive advantage (De Geus, 1988). 
As far back as 1970, it was noted that one of the challenges of SMEs is how to assist small organizations in developing their human resources (Walton, 1999). Research evidence has consistently shown that SMEs provide less formal training than larger firms (Patton, 2005). The problem is that SMEs do not send people on formal training whether external or internal. According to Walton (1999), the view that SMEs are less likely to engage in formal training provision than larger concerns is a well-rehearsed position. Many small and medium-sized enterprises in Nigeria pay lip service to human capital development in spite of the strategic role of this sub-sector to national development. Many SMEs are confronted with enormous challenges in human capital development and the attraction of talents from the external labour market. Those that appreciate the need for human capital development embark on it haphazardly without proper implementation and evaluation. Training in SMEs has been described as informal and on-the-job, with little or no provision for management development and no career development (Marlow \& Patton, 1993; and Storey, 1994). Many challenges confront the planning and execution of human capital development in Nigerian SMEs, such as negative training philosophy. Many owner-managers of SMEs believe that training and development is not imperative. They hold the view that training/development is a waste of resources and efforts as they pay lip service to training, both on and off the job (Fajana, 1995). According to McMahon and Murphy (1999), training is often perceived as an unaffordable luxury involving not only course fees, but also the cost of unproductive labour. This is consistent with the observation of Fajana (1995) who argues that this negative belief is fuelled by glut of skilled yet unemployed people in the Nigerian labour market. Fear of poaching is also a challenge facing human capital development in SMEs. Many SMEs have the phobia that should they spend fortunes in training their employees, one day they could be poached by competitors, thereby rendering their efforts and resources futile. According to Storey (1994), poaching of staff is greater from small firms, partly because wage rates are lower than in large firms.

Apathy among owner-managers is a challenge confronting human capital development. Many ownermanagers of SMEs display apathy or lack of interest in training their employees. This may not be unconnected with their negative philosophy. There is also the absence of training policies. Many SMEs do not have laid-down guidelines governing training and development programmes. In other words, there exists no training policy to provide guidance to managers as to the type of training needed, those due for training, training budget, as well as responsibility for training and development inter-alia. Lack of training needs analysis is yet another challenge. Many SMEs embark on training and development haphazardly without embarking on needs analysis. McMahon and Murphy (1999) noted that SMEs rarely carry out formal training needs analysis and have no systematic approach to training. They train for training sake, without having a demonstrated training need. In most cases, there is subjective selection of participants for training and development. According to Stahl, NyHan, and D'Aloja (1993), SMEs lack the capacity to define their real training needs and also lack the capacity to plan, organize, and implement training. The deficiency model approach to training and development is yet another challenge. Many SMEs view training/development as a means to remedy a deficiency and only embark on training whenever there exists a deficiency. Human capital development is much more than correcting a deficiency. It could be used to increase all round competencies (Armstrong, 2001), multi-skilling, multi-tasking or functional flexibility. Human capital development is viewed as a cost rather than benefit with a pay-off. Many SMEs hold the view that whatever resources are expended on developing employees is a waste or cost without examining the long-term benefits derivable from the exercise. According to Altarawneh (2009), some organizations view training as an overhead and not an investment. They hold the view that training is a vacation activity or leisure time pursuit which is given to some people, normally to the managers' relatives and friends.

Threat or fear of job take-over by subordinates is also a challenge. Many managers of SMEs, because of the fear of job take-over by subordinates, feel threatened to recommend their subordinates for training programmes whenever the opportunity arises. This is made worse if the manager does not possess requisite qualifications. Inadequate or no budget allocated to human capital development is also one of the problems facing SMEs. This problem subsists in organizations without sound training/development policies. Many SMEs do not have a budget for training and development. Obokoh (2008) asserts that one of the problems of the SMEs is the inability to employ a skilled labour force as a result of small budgets to manage specialised areas of their business.

Incessant environmental changes are also a challenge. This obstacle is beyond the control of the organization. This is evidenced in economic vagaries and technological shifts. For instance, during favourable economic conditions, many organizations embrace training and development, but during unfavourable economic 
conditions, they shy away from embarking on training and development. The rapidity in technological shifts often renders acquired skills/knowledge obsolete, thereby necessitating the need for retraining programmes on the part of the organization. This, of course, involves huge expenditures which many SMEs cannot afford. Improper evaluation of a training/development programme is yet another problem confronting SMEs. According to Altarawneh (2009), in some Arab organizations, evaluation of training and development is rarely undertaken. The efficacy, or otherwise, of training programmes could be ascertained through proper evaluation exercises. However, many SMEs do not embark on training/development evaluation with a view to discovering the strengths and weaknesses of such programmes.

\section{METHOD}

This study adopted the survey research design. With a view to eliciting information from respondents, a self-developed questionnaire was designed using a 5-point Likert scale ranging from strongly agree (5) to strongly disagree (1). The instrument has two sections: Section A has nine items which sought the views and opinions of respondents on the challenges of human capital development in SMEs. Section B has eight items which elicited the demographic profiles of respondents. A total of 165 questionnaires were distributed to the target population using the purposeful (judgmental) sampling technique. This sampling technique is in line with Coetzer (2006). The questionnaires were self-administered to respondents with the help of three research assistants. However, 140 were returned upon which the data analysis was based. This represents an $85 \%$ response rate. Data analysis was carried out with the aid of SPSS (Statistical Package for Social Sciences).

\section{RESULTS}

Table 1 shows the descriptive statistics of primary data generated from the field.

Table 1: Descriptive Statistics of Primary Data

\begin{tabular}{|c|c|c|c|c|c|c|c|c|c|}
\hline $\mathbf{S} / \mathbf{N}$ & Variables & $\mathbf{N}$ & $\mathbf{S A}$ & $\mathbf{A}$ & UN & D & SD & MIS & STD \\
\hline & & & 5 & 4 & 3 & 2 & 1 & & \\
\hline 1 & $\begin{array}{l}\text { SMEs engage in human capital development } \\
\text { haphazardly without embarking on need analysis. }\end{array}$ & 136 & $\begin{array}{c}(32) \\
22.9 \% \\
\end{array}$ & $\begin{array}{c}(40) \\
28.6 \% \\
\end{array}$ & $\begin{array}{c}(40) \\
28.6 \% \\
\end{array}$ & $\begin{array}{c}(18) \\
12.9 \% \\
\end{array}$ & $\begin{array}{c}(6) \\
4.3 \% \\
\end{array}$ & 3.54 & 1.12 \\
\hline 2 & $\begin{array}{l}\text { The unwillingness of skilled labour to be retained } \\
\text { in the firm impacts negatively on the survival of } \\
\text { SMEs in Nigeria. }\end{array}$ & 138 & $\begin{array}{c}(51) \\
36.4 \%\end{array}$ & $\begin{array}{c}(51) \\
36.4 \%\end{array}$ & $\begin{array}{c}(20) \\
14.3 \%\end{array}$ & $\begin{array}{l}(13) \\
9.3 \%\end{array}$ & $\begin{array}{c}(3) \\
2.1 \%\end{array}$ & 3.97 & 1.05 \\
\hline 3 & $\begin{array}{l}\text { Inadequate budget is allocated to human resource } \\
\text { development in SMEs. }\end{array}$ & 140 & $\begin{array}{c}(48) \\
34.3 \%\end{array}$ & $\begin{array}{c}(58) \\
41.4 \%\end{array}$ & $\begin{array}{c}(18) \\
12.9 \%\end{array}$ & $\begin{array}{l}(14) \\
10.0 \%\end{array}$ & $\begin{array}{l}(2) \\
1.4 \%\end{array}$ & 3.97 & 1.00 \\
\hline 4 & $\begin{array}{l}\text { Many SMEs do not embark on } \\
\text { training/development evaluation with a view to } \\
\text { discovering the strengths and weaknesses of such } \\
\text { programmes. }\end{array}$ & 140 & $\begin{array}{c}(51) \\
36.4 \%\end{array}$ & $\begin{array}{c}(55) \\
39.3 \%\end{array}$ & $\begin{array}{c}(24) \\
17.1 \%\end{array}$ & $\begin{array}{c}(8) \\
5.7 \%\end{array}$ & $\begin{array}{l}(2) \\
1.4 \%\end{array}$ & 4.04 & 0.95 \\
\hline 5 & $\begin{array}{l}\text { Human capital development is viewed as a cost } \\
\text { rather than benefit with a pay -off in SMEs }\end{array}$ & 139 & $\begin{array}{c}(38) \\
27.1 \% \\
\end{array}$ & $\begin{array}{c}(56) \\
40.0 \% \\
\end{array}$ & $\begin{array}{c}(27) \\
19.3 \%\end{array}$ & $\begin{array}{c}(14) \\
10.0 \%\end{array}$ & $\begin{array}{c}(4) \\
2.9 \% \\
\end{array}$ & 3.79 & 1.05 \\
\hline 6 & $\begin{array}{l}\text { SMEs provide less formal training than larger } \\
\text { firms }\end{array}$ & 138 & $\begin{array}{c}(47) \\
33.6 \% \\
\end{array}$ & $\begin{array}{c}(60) \\
42.9 \% \\
\end{array}$ & $\begin{array}{l}(13) \\
9.3 \% \\
\end{array}$ & $\begin{array}{c}(16) \\
11.4 \% \\
\end{array}$ & $\begin{array}{c}(2) \\
1.4 \% \\
\end{array}$ & 3.97 & 1.02 \\
\hline 7 & $\begin{array}{l}\text { Many SMEs do not have laid down policies } \\
\text { governing training and development programmes. }\end{array}$ & 140 & $\begin{array}{c}(48) \\
34.3 \% \\
\end{array}$ & $\begin{array}{c}(50) \\
35.7 \% \\
\end{array}$ & $\begin{array}{c}(28) \\
20.0 \% \\
\end{array}$ & $\begin{array}{l}(13) \\
9.3 \%\end{array}$ & $\begin{array}{c}(1) \\
0.7 \% \\
\end{array}$ & 3.94 & 0.99 \\
\hline 8 & $\begin{array}{l}\text { Many owner managers display apathy or lack of } \\
\text { interest in training their employees for fear of } \\
\text { being poached by competitors. }\end{array}$ & 140 & $\begin{array}{c}(65) \\
46.4 \%\end{array}$ & $\begin{array}{c}(45) \\
32.1 \%\end{array}$ & $\begin{array}{l}(12) \\
8.6 \%\end{array}$ & $\begin{array}{c}(15) \\
10.7 \%\end{array}$ & $\begin{array}{c}(3) \\
2.1 \%\end{array}$ & 4.10 & 1.08 \\
\hline 9 & $\begin{array}{l}\text { Many SMEs have negative training philosophy } \\
\text { and pay lip service to human resource } \\
\text { development. }\end{array}$ & 140 & $\begin{array}{c}(37) \\
26.4 \%\end{array}$ & $\begin{array}{c}(73) \\
52.1 \%\end{array}$ & $\begin{array}{c}(20) \\
14.3 \%\end{array}$ & $\begin{array}{c}(8) \\
5.7 \%\end{array}$ & $\begin{array}{c}(2) \\
1.4 \%\end{array}$ & 3.96 & 0.88 \\
\hline
\end{tabular}

Source: Field Survey, 2010. Legend: N= Respondents: SA= strongly agree: $A=$ Agree: $\quad$ UN=undecided/ indifference: $D=$ disagree: $\mathrm{SD}=$ strongly disagree: $\mathrm{MIS}=$ mean Item Score: $\mathrm{STD}=$ standard deviation. 
Table 2 displays the demographic profiles of respondents to the survey.

Table 2: Demographic Profiles of Respondents

\begin{tabular}{|c|c|c|c|}
\hline $\mathbf{S} / \mathbf{N}$ & Variables & Absolute Frequency & Relative Frequency \\
\hline \multirow[t]{3}{*}{1.} & Sex of Respondents & & \\
\hline & Male & 84 & $60 \%$ \\
\hline & Female & 51 & $36.4 \%$ \\
\hline \multirow[t]{6}{*}{2.} & Age of Respondents & & \\
\hline & Less than 20years & 3 & $2.1 \%$ \\
\hline & $20-29$ & 35 & $25.0 \%$ \\
\hline & $30-39$ & 50 & $40.0 \%$ \\
\hline & $40-49$ & 29 & $20.7 \%$ \\
\hline & 50 and above & 12 & $8.6 \%$ \\
\hline \multirow[t]{3}{*}{3.} & Marital Status & & \\
\hline & Married & 103 & $73.6 \%$ \\
\hline & Single & 30 & $21.4 \%$ \\
\hline \multirow[t]{8}{*}{4.} & Qualifications & & \\
\hline & OND & 19 & $13.6 \%$ \\
\hline & HND & 17 & $12.1 \%$ \\
\hline & First degree & 49 & $35.0 \%$ \\
\hline & Masters & 23 & $16.4 \%$ \\
\hline & Ph.D & 2 & $1.4 \%$ \\
\hline & Professional diploma & 19 & $13.6 \%$ \\
\hline & Others & 7 & $5.0 \%$ \\
\hline \multirow[t]{4}{*}{5.} & Job Category & & \\
\hline & Junior & 31 & $22.1 \%$ \\
\hline & Senior & 67 & $47.9 \%$ \\
\hline & Management Staff & 38 & $27.1 \%$ \\
\hline \multirow[t]{4}{*}{6.} & Organizational Size & & \\
\hline & Less than 10 staff & 22 & $15.7 \%$ \\
\hline & 10-49 staff & 54 & $38.6 \%$ \\
\hline & $50-250$ staff & 57 & $40.7 \%$ \\
\hline \multirow[t]{5}{*}{7.} & Business/Activity Engaged in & & \\
\hline & Manufacturing & 18 & $12.9 \%$ \\
\hline & Service & 78 & $55.7 \%$ \\
\hline & Commercial/ trade & 28 & $20 \%$ \\
\hline & Others & 12 & $8.6 \%$ \\
\hline \multirow[t]{5}{*}{8.} & Ownership/Control & & \\
\hline & Owner-managed & 57 & $40.7 \%$ \\
\hline & Partnership & 42 & $30.0 \%$ \\
\hline & Family business & 19 & $13.6 \%$ \\
\hline & Others & 16 & $11.4 \%$ \\
\hline
\end{tabular}

Source: Field Survey, 2010

\section{DISCUSSION OF FINDINGS}

Based on the analysis of data, it was found that $52 \%$ of the respondents agreed and strongly agreed that SMEs engage in human capital development haphazardly without embarking on needs analysis. This finding is consistent with the findings of Stahl, NyHan \& D'Aloja (1993) and McMahon \& Murphy (1999). Seventy-three percent of the respondents agreed and strongly agreed that the unwillingness of skilled labour to be retained in the firm impacts negatively on the survival of SMEs in Nigeria. Seventy-six percent of the respondents agreed and strongly agreed that an inadequate budget is allocated to human resource development in SMEs. This finding corroborates the views of Obokoh (2008) who asserts that one of the problems of the SMEs is the inability to employ a skilled labour force as a result of small budgets, to manage specialized areas of their business. Seventy-six 
percent of the respondents agreed and strongly agreed that many SMEs do not embark on a training/development evaluation with a view to discovering the strengths and weaknesses of such programmes. This finding is consistent with the findings of Altarawneh (2009). Sixty-seven percent of the respondents agreed and strongly agreed that human capital development is viewed as a cost rather than a benefit with a pay-off in SMEs. This is in line with the findings of McMahon \& Murphy (1999) and Altarawneh (2009). Seventy-seven percent of the respondents agreed and strongly agreed that SMEs provide less formal training than larger firms. This supports the findings of Patton (2005) and Walton (1999). Seventy percent of the respondents agreed and strongly agreed that many SMEs do not have laid down policies governing training and development programmes. According to Fajana (1995), some SMEs do appreciate the need for training, but these are poorly implemented. This poor implementation may not be unconnected with lack of laid down policies. Seventy-nine percent of the respondents agreed and strongly agreed that many owner-managers display apathy or lack of interest in training their employees for fear of being poached by competitors. This finding is consistent with Storey (1994). According to Storey (1994), poaching of staff is greater from small firms, partly because wage rates are lower than what is obtained in large firms. More so, $79 \%$ of respondents agreed and strongly agreed that many SMEs have a negative training philosophy and pay lip service to human resource development. This finding corroborates the views of Fajana (1995).

\section{CONCLUSION AND RECOMMENDATIONS}

The contribution of human capital development in SMEs in Nigeria is enormous. Owing to changes in technology and to avoid skill obsolescence, pattern of training or development should be conceived as a continuous exercise throughout the working life in SMEs. From time to time, training needs of a job should be identified so as to determine the best way to meet the needs. Human capital development should be extended to the newly employed, as well as old employees in small and medium-sized enterprises. The human element is the most valuable asset at the disposabal of organizations. In fact, organizations are people. The heart and soul of any organization is the human capital and human capital development in SMEs should not be down-played if the desired corporate and national goals are to be realized. SMEs should embrace a positive human capital development philosophy and should strive to provide both formal and informal training opportunities for their workforce. Policies should be put in place to provide guidelines for human capital development in Nigerian SMEs. Small and medium-sized enterprises should adopt the investor in people criteria. These criteria are to review the human capital development needs of all employees with a view to determining the best way of meeting the needs. An investor in people makes an effort to train and develop employees from the point of entry via recruitment and throughout their employment, as well as evaluate the investment in human capital development to assess achievement and improve future effectiveness.

\section{AUTHOR INFORMATION}

Christopher O. Chidi, B.Sc (Hons)., M.Sc., and Ph.D. (in view) in Industrial Relations \& Personnel Management. I am a faculty member of the department of Industrial Relations and Personnel Management, Faculty of Business Administration, University of Lagos, Nigeria. I possess considerable experience in the theory and practice of HRM and Industrial Relations in the public and private sectors. I teach courses in HRM, Industrial Relations, Research Methods, Organizational Behaviour, Industrial Psychology, Industrial Sociology and Business Communication. My research interests include Human Capital Resourcing, Employee Retention, HRM, Industrial Relations and Organizational Behaviour. I belong to the following professional associations, ACIPMN, ANITAD and MNIRA.

Oluseyi A. Shadare, BA (Hons)., M.ED (Industrial Relations)., Ph.D. (Industrial Relations), LLB, Barrister-at-Law (BL). I am a faculty member of the department of Industrial Relations and Personnel Management, Faculty of Business Administration, University of Lagos, Nigeria. I have extensive experience in the field of Human Resource Management and Industrial Relations, Marketing and Law. I teach the following courses at undergraduate and postgraduate levels, Labour Law, Comparative Industrial Relations, Human Resource Planning, Human Resource Management and Compensation Management. My research interests are Industrial Relations, Human Resource Management and Labour Law. I belong to the following professional bodies, ACIPMN, ACIM, NBA and AMTN 


\section{REFERENCES}

1. Altarawneh, I. (2009). "Training and Development Evaluation in Jordanian Banking Organizations."Research and Practice in HRM. 17(1), pp. 1-23

2. Ariyo, D. (2000). "Small Firms are the Backbone of the Nigerian Economy". Africa Economic Analysis. Accessed from $\mathrm{http} / / \mathrm{www}$.afbis.com/analysis/small.htm.

3. Armstrong, M (2006). A Handbook of Human Resource Management Practice. (10 ${ }^{\text {th }}$ ed.). U.K: Kogan Page Ltd.

4. Armstrong, M. (2001). A Hand Book of Human Resources Management Practice ( $8^{\text {th }}$ ed). U.K: Kogan Page Ltd.

5. Armstrong, M. (1984). A Hand Book of Human Resources Management Practice (2nd ed). U.K: Kogan Page Ltd.

6. Ayeni, O. (2003). "Relationship between Training and Employment of Technical College Graduates in Oyo State between 1998 and 2001". Unpublished Ph.D Thesis. University of Ibadan.

7. Banjoko, S.A. (2002). Human Resource Management: An Expository Approach. Lagos: Pumark Nigeria Ltd (Educational Publishers)

8. $\quad$ Becker, G. S. (1964). Human capital. New York: Columbia University Press.

9. Bontis, N., Dragonetti, N.C., Jacobsen, K. \& Roos, G. (1999). "The Knowledge Toolbox: A Review of the Tools Available to Measure and Manage Intangible Resources." European Management Journal. 17(14), pp. 391-402

10. Boud, D. \& Garrick, J. (1999). “Understanding of Workplace Learning”. In Boud, D. (ed) Understanding Learning at Work (pp.1-11). London: Routledge.

11. Cameron, A.F., \& Massey, C. (1999). Small and Medium Sized Enterprises: A New Zealand Perspective. Auckland, New Zealand: Longman

12. Coetzer, A.J. (2006). "Developing Human Capital in Small Firms: A Conceptual Framework for Analysing the Effects of Managers on Employee Learning. Research and Practice in Human Resource Management. 14(1), pp.143-179

13. De Geus, A.P. (1988). "Planning as Learning". Harvard Business Review. 66(2), 70-74.

14. Fajana, S. (2002). Human Resource Management: An introduction. Lagos: Labofin \& Company.

15. Fajana, S. (1995). "Managing Human Resources for Productivity in Small and Medium-Sized Enterprises". In Ojo, A.T (ed.) Management of Small and Medium Scale Enterprises in Nigeria. (pp.121-134). Lagos: Pumark Nig. Ltd (Educational Publishers)

16. Harbison, F.H (1973). Human Resources as the Wealth of Nations. New York: Oxford University Press.

17. Heneman III, H.G. \& Judge, T.A. (2006). Staffing Organization ( $5^{\text {th }}$ ed). New York: McGraw-Hill/ Irwin

18. Honey, P \& Mumford, A (1996) .The Manual of Learning Styles, (.3rd ed) Maidenhead:Honey Publications.

19. Inegbenebor, A, U. (1995). "Size, Structure and Performance of Private Nigerian Manufacturing Enterprises.” In Ojo, A.T (ed.) Management of Small and Medium Scale Enterprises in Nigeria. (pp.45-57). Lagos: Pumark Nig. Ltd (Educational Publishers)

20. Katwalo, A.M. \& Madichie, N. O. (2008). "Entrepreneurial and Cultural Dynamics: A Gender Kaleidoscope of Ugandan Microenterprise". International Journal of Entrepreneurship and Small Business. Vol. 5, No. 3/ 4, pp. 337-348.

21. Lawal, A.A \& Sulaimon, A. (2007). "Social Responsibility and Organizational Effectiveness of Small and Medium Enterprises in the Contemporary Environment”. Lagos Organization Review. Vol.4 № 7.pp. 6376.

22. Lawal, A.A. (2005). "Management Practices and Organizational Effectiveness of Nigerian Small and Medium Enterprises (SMEs) in Lagos State". Unpublished Ph.D Thesis, University of Lagos.

23. MacMahon, J. \& Murphy, E. (1999). "Managerial Effectiveness in Small Enterprises: Implications for HRD." Journal of European Industrial Training. 23(1), pp.25-35

24. Marlow, S. \& Patton, D. (1993). "Managing the Employment Relationship in the Smaller Firm: Possibilities for Human Resource Management."International Small Business Journal. 11(4), pp.57-64

25. Mumford, A. \& Gold, J. (2004). Management Development: Strategies for Action, CIPD. 
26. Obikoya, J.O. (1995). "Small and Medium Enterprises in Nigeria: Problems and Prospects" In Ojo, A.T (ed.) Management of Small and Medium Scale Enterprises in Nigeria. (pp.246-256). Lagos: Pumark Nig. Ltd (Educational Publishers)

27. Obisi, C. (1996) Personnel Management. Ibadan: Jackbod Enterprises.

28. Obokoh, L. O. (2008). "Small and Medium Sized Enterprises Development under Trade Liberalisation: A Survey of Nigerian Experience". International Journal of Business and Management. Vol.3, №. 12, pp.92-101

29. Odekunle, S.O. (2001). "Training and Skill Development as Determinant of Workers' Productivity in the Oyo State Public Service”. Unpublished Ph.D Thesis, University of Ibadan.

30. Ojo, F. (1998). Personnel Management: Theories and Issues. Lagos: Panaf Publishing Inc.

31. Okpala, P.O \& Chidi, O.C (2010) "Human Capital Accounting and its Relevance to Stock Investment Decisions in Nigeria". European Journal of Economics, Finance and Administrative Sciences. Issue 21, pp.64-76

32. Olaniyan, D.A. \& Okemakinde. T. (2008). "Human Capital Theory: Implications for Educational Development" European Journal of Scientific Research Vol.24 No.2, pp.157-162

33. Owuala, S.I. (1999). Entrepreneurship in Small Business Firms. Lagos: G-MAG Investment Ltd.

34. Owuala, S.I. (1987). "The Role of Small Scale Enterprises in the Economic Development of Nigeria." Management in Nigeria, Nov-Dec., pp.30-42

35. Patton, D. (2005). "Training in Smaller Firms". In Marlow, S., Patton, D., \& Ram, M. (eds.) Managing Labour in Small Firms (pp.83-108).London: Routledge.

36. Pearson, T.R., Stringer, D.Y., Mills, L.H \& Summers, D.F (2006). "Urban vs. Rural: Human Resource Management in SMEs. Academy of Entrepreneurship Journal. Vol.12, №. 2, pp.29-46

37. Price, A. (2004). Human Resource Management in a Business Context. ( $2^{\text {nd }}$ ed). London: Thomson Learning

38. Psacharopoulos, G. \& Woodhall, M. (1997). Education for Development: An Analysis of Investment Choice. New York: Oxford University Press.

39. Sakamota, A. \& Powers, P.A. (1995). "Education and the Dual Labour Market for Japanese Men" American Sociological Review. 60 (2), pp. 222-246.

40. Schultz, T. W. (1961). "Investment in Human Capital". American Economic Review.51, March, pp 1-17

41. Stahl, T., NyHan, B., \& D’Aloja, P. (1993). The Learning Organization: A Vision for Human Resource Development. EUROTECNET.

42. Storey, D. (1994). Understanding the Small Business Sector. London: Thomson Business Press.

43. Van-Den-Berg, H. (2001). Economic Growth and Development (International Edition). New York: McGraw-Hill Companies, Inc.

44. Walton, J. (1999). Strategic Human Resource Development. U.K: Pearson Education Ltd.

45. Williams, A. (1998). "Organizational Learning and the Role of Attitude Surveys." Human Resource Management Journal. 8(4), pp. 51-65 


\section{NOTES}

